\title{
Multiplex PCR assays for qualitative detection and identification of the GT73, Ms8, Rf3 and T45 varieties of genetically modified oilseed rape
}

\author{
M. Mazur', Z. Sieradzki, B. Król and K. Kwiatek \\ National Veterinary Research Institute in Puławy, Department of Hygiene of Animal Feedingstuffs
}

al. Partyzantów 57, 24-100 Puławy, Poland

KEY WORDS: genetically modified rape, multiplex PCR, detection, identification, feedstuffs

Received: 25 August 2016

Revised: $\quad 7$ April 2017

Accepted: 7 June 2017

${ }^{1}$ Corresponding author:

e-mail: mwalczak@piwet.pulawy.pl

\begin{abstract}
Polymerase chain reaction (PCR) has become the main method for detection and identification of genetically modified organisms (GMOs). Multiplex PCR is a variation of this technique allowing simultaneous amplification of several targets in the same reactions. In this study, it was developed, optimized and performed in-house validation of the multiplex PCR method for detection and identification of genetically modified rape lines (GT73, Ms8, Rf3 and T45) in two types of assays: gene- and event-specific. The optimized reactions exhibited high specificity, sensitivity, selectivity and accuracy. The limit of detection (LOD) for the gene-specific reaction was $0.01 \%$ for each of the tested lines of rape. For the event-specific reaction, LOD was at the same level for most of the GM rape lines except for $\mathrm{T} 45(\mathrm{LOD}=0.025 \%)$. The optimized and validated assays were employed from 2012 to 2015 in our laboratory to analyse 428 samples of animal feedstuffs containing oilseed rape. GM rape was not detected in the analysed feedstuffs until 2013 (only some traces of GM soyabean were found). Since 2014, the GM rape presence has been confirmed in event-specific reactions in more than one third of analysed samples.
\end{abstract}

\section{Introduction}

Over the last two decades, the number of available genetically modified organisms (GMOs) has been increasing greatly and continuously. Concomitantly with the development of transgenic crops, regulations regarding proper labelling of such products have been introduced, which in turn has forced progress in the molecular methods allowing appropriate detection and identification of such organisms. The main molecular technique that is used for this purpose is polymerase chain reaction (PCR), because it is generally accepted as the most sensitive and specific. There is a variety of PCR-based meth- ods applied for detection of GMO, which can be grouped into four different categories depending on their specificity (Miraglia et al., 2004; Holst-Jensen et al., 2012). The first category comprises screening tests targeting for DNA sequences widely used in the construction of various GM crops. The target sequence includes promoters (e.g., 35S promoter of the cauliflower mosaic virus - CaMV 35S promoter) or terminators (e.g., terminator of the cauliflower mosaic virus - CaMV T-35S and terminator of the nopaline synthase gene - T-NOS), which allow proper expression of the introduced transgene as well as selection markers commonly present in vectors used for genetic modification (nptII - neo- 
mycin phosphotransferase II; bla - $\beta$-lactamase) (Marmiroli et al., 2008; Dörries et al., 2010). The positive amplification of one of these elements does not always indicate the presence of GMO, because they naturally occur in some viruses, bacteria and plants; therefore, this method is associated with a particular risk of false positive results (Holst-Jensen et al., 2012). The next categories of PCR-based GMO detection methods encompass so-called gene-specific reactions, which allow detection of a target gene responsible for the desired feature of GMOs and construct-specific assays for detection of a junction site between different elements of the vector carrying the transgene (Holst-Jensen et al., 2003; Marmiroli et al., 2008). These methods are more specific in comparison to screening tests, but once again, the same target genes or constructspecific elements are often used in preparation of various GMOs. Finally, to overcome this problem, event-specific assays have been developed, which are the most specific reactions for identification of GMOs. They target a unique site comprising a junction between the transgenic insert and the host genome (Holst-Jensen et al., 2003; Yang et al., 2006; Marmiroli et al., 2008; Dörries et al., 2010). Different varieties of polymerase chain reactions are commonly used for monitoring of GMOs in foods and animal feeds (Shin et al., 2013; Kim et al., 2014; Meriç et al., 2014; Datukishvili et al., 2015; Turkec et al., 2016). Nowadays real-time PCR (qPCR) has become a gold standard in the routine analysis of GMOs, allowing very sensitive detection and especially quantification of GMOs in test samples (Dörries et al., 2010; Elsanhoty et al., 2013; Özgen Arun et al., 2013, Zdjelar et al., 2013; Fernandes et al., 2014; Kim et al., 2014; SantaMaria et al., 2014; Turkec et al., 2016). However, to quantify GMO content using qPCR, it is necessary to plot standard curves for both the reference gene and transgen, using serial dilutions of DNA extracted from the reference material, which is time-consuming. The efficiency of qPCR and therefore quantification can be further influenced by inhibitors present in food or feed samples, leading to under- or overestimation of the GMO content. The problem of performing quantitative determination may also arise from the absence of reference materials needed to plot standard curves. A digital droplet PCR (ddPCR) assay solves many of these problems: using such a technique, GMO content can be determined directly by measuring the amount of the transgene in relation to the reference gene without standard curves. Nevertheless, it is a relatively new technique, so the applicability of ddPCR in routine analysis of GM food and feed has not yet been widely demonstrated (Dobnik et al., 2016; Gerdes et al., 2016; Iwobi et al., 2016).

Oilseed rape is one of the major crop species used in animal feeding in many countries. GM rapeseed is not commercially grown in the European Union, but several lines, e.g., GT73, Ms8xRf3 and T45, have been approved for production and use as human food and animal feed. The GM rape line GT73 is resistant to the herbicide glyphosate. Two genes, i.e. 5-enolpyruvylshikimate-3-phosphate synthase (epsps) derived from Agrobacterium sp. strain CP4 and glyphosate oxidoreductase gene (goxv247) originally isolated from Ochrobactrum anthropi strain LBAA confer tolerance to this herbicide. The line of GM rape designated as Ms8xRf3 has the bar gene from Streptomyces hygroscopius, encoding the enzyme phosphinothricin-acetyltransferase (PAT) which contributes to increased tolerance to glufosinate-containing herbicides. The Ms8xRf3 GM variety is an example of a genestacked GM plant, which is a hybrid produced by conventional crossing from well described parental lines MS8 and RF3. The rape line designated T45, which is also authorized for use in EU, contains the pat gene derived from Streptomyces viridochromogenes. This rape variety is also tolerant to glufosinate-ammonium (http://www.gmo-compass.org).

The aim of this study was to develop and validate effective methods for detection and identification of GM rape by multiplex PCR (mPCR). The simultaneous amplification of several targets is a very useful strategy reducing sample loads, time and resources. Such approach has been successfully developed for detection and identification of various GMOs. The mPCR assays described in this work were based on two types of reaction: genespecific and event-specific and were successfully applied in GMO detection for several past years (from 2012 to 2015).

\section{Material and methods}

\section{Plant material}

Three varieties of GM rape: GT73, Ms8xRf3 and T45 as well as non-GM rape were obtained from the American Oil Chemists' Society (AOCS). GT73 and non-GM rape plant materials were obtained as ground seeds; for the other GM lines, DNA from leaf tissue was used. The other transgenic crops, i.e. GM maize (events Bt11, Bt176, MON810, 1507, NK603, 
GA21, MIR604, MON863, 59122), soyabean (event GTS 40-3-2, Roundup Ready Soya, 305423, 356043) and cotton (events 281-24-236x3006-210-23, GHB $119)$, which were used in validation process, were Certified Reference Materials (CRM) from JRCIRMM (Joint Research Centre - Institute for Reference Materials and Measurements) or obtained from AOCS as a powder produced from seeds. Genomic DNA provided by Eurofins GeneScan was used as reference material for GM maize event T25. The samples containing oilseed rape as compound feed, rapeseed cake and rapeseed were collected by the Polish Veterinary Inspectorate. The sampling was done in accordance to the Polish Multiannual Programme of the National Veterinary Research Institute in Puławy (NVRI).

\section{DNA extraction}

The genomic DNA was isolated from the reference materials and rape samples using cetyl trimethylammonium bromide (CTAB; Sigma-Aldrich, St. Louis, MO, USA) as described in EN ISO 21571 (2005). After the extraction, the quality and concentration of DNA were measured by the $260 / 280 \mathrm{~nm}$ absorbance ratio (Nicolete Evolution 300 spectrophotometer, Thermo Fisher Scientific, Waltham, MA, USA). If the DNA absorption ratio A260/A280 exceeded the range of 1.7-2.0, indicating poor quality of the extracted DNA, it was further purified using a QIAquick PCR Purification Kit (Qiagen, Hilden, Germany).

\section{Oligonucleotide primers and mPCR conditions}

The oligonucleotides used as primers for the PCR analysis (Table 1) were commercially synthesized by Genomed (Warsaw, Poland), with the HPLC purification step performed by the supplier. Four sets of primer pairs were used for gene-specific mPCR allowing detection of a pep gene fragment (phosphoenolpyruvate carboxylase - rape endogenous gene) and the genes of interest: epsps, bar and pat for GT73, Ms8xRf3 and T45, respectively. In the mPCR targeting for identification of GM events, another four sets of primers were used. These specific primers facilitated amplification of a junction region between the host DNA and the transgenic insert. Several parameters of PCR amplification were initially assessed to optimize the conditions for $\mathrm{mPCR}$. These parameters included concentrations of $\mathrm{MgCl}_{2}$ (1.5 mM, $2.5 \mathrm{mM}, 3.5 \mathrm{mM}$ ), dNTP (deoxynucleotide solution mix; $0.1 \mathrm{mM}, 0.2 \mathrm{mM}, 0.3 \mathrm{mM}$ ) and primers $(0.05-0.2 \mu \mathrm{M})$ for every type of reaction. Moreover, numerous profiles of PCR such as primer annealing temperature $\left(53-63{ }^{\circ} \mathrm{C}\right)$, time $(30-60 \mathrm{~s})$ and number of cycles (35-40) were tested.

The optimized mPCRs were performed in a final volume of $25 \mu \mathrm{l}$ of reaction mixture containing 1x buffer (Applied Biosystems by Life Technologies, Thermo Fisher Scientific, Waltham, MA, USA), $2.5 \mathrm{mM} \mathrm{MgCl}_{2}$ (Applied Biosystems by Life Technologies, Thermo Fisher Scientific, Waltham, MA, USA), $0.2 \mathrm{mM}$ dNTP (Invitrogen, Carlsbad,

Table 1. List of primer sequences for multiplex PCR

\begin{tabular}{|c|c|c|c|c|}
\hline Primer name & Orientation sequence $5^{\prime} \rightarrow 3^{\prime}$ & Target (gene or site) & Amplicon size, bp & Source \\
\hline \multicolumn{5}{|l|}{ Gene-specific } \\
\hline PEP3-5 & GCTAGTGTAGACCAGTTCTTG & \multirow{2}{*}{ pep } & \multirow{2}{*}{248} & \multirow{2}{*}{ Hellebrand et al., 1998} \\
\hline PEP3-6 & САСTCTTGCCTCTTGTCCTC & & & \\
\hline $\begin{array}{l}\text { 4EPSPSF } \\
\text { 4EPSPSR }\end{array}$ & $\begin{array}{l}\text { AACGCAAATCTCCCTTATCGG } \\
\text { GACCTCCAAACATGAAGGACCT }\end{array}$ & epsps & 274 & Demeke et al., 2002 \\
\hline $\begin{array}{l}\text { Bar-CRP4 } \\
\text { Bar-CFP4 }\end{array}$ & $\begin{array}{l}\text { GACAGCGACCACGCTCTT } \\
\text { GCAACGCCTACGACTGGAC }\end{array}$ & bar & 137 & Demeke and Ratnayaka, 2008 \\
\hline $\begin{array}{l}\text { PatF } \\
\text { PatR }\end{array}$ & $\begin{array}{l}\text { CGCGGTTTGTGATATCGTTAAC } \\
\text { TCTTGCAACCTCTCTAGATCATCAA }\end{array}$ & pat & 108 & Zeitler et al., 2002 \\
\hline \multicolumn{5}{|l|}{ Event-specific } \\
\hline $\begin{array}{l}\text { GT1F } \\
\text { GT1R }\end{array}$ & $\begin{array}{l}\text { TGAACTTTCCTTTATGTAATTTTCCAGAA } \\
\text { GCTTATACGAAGGCAAGAAAAGGA }\end{array}$ & $\begin{array}{l}\text { 3'-integration } \\
\text { junction }\end{array}$ & 522 & Yang et al., 2007 \\
\hline $\begin{array}{l}\text { Ms8RV-1 } \\
\text { Ms8RG-1 }\end{array}$ & $\begin{array}{l}\text { TTGCCTTTTCTTATCGACCATGTACTC } \\
\text { AACCTTGAGGACGCTTTGATCATATTC }\end{array}$ & $\begin{array}{l}\text { 3'-integration } \\
\text { junction }\end{array}$ & 123 & Wu et al., 2008 (modified) \\
\hline $\begin{array}{l}\text { Rf3RV } \\
\text { Rf3RG }\end{array}$ & $\begin{array}{l}\text { TTCTTTCAAGATGGGAATTAACATCT } \\
\text { TTTGTACAAAACTTGGACCCCTAGGT }\end{array}$ & $\begin{array}{l}\text { 3'-integration } \\
\text { junction }\end{array}$ & 92 & Wu et al., 2008 \\
\hline $\begin{array}{l}C-1 F \\
C-2 R\end{array}$ & $\begin{array}{l}\text { TCCCATTTATTTACGGTCAC } \\
\text { CCATGGGAATTCATTTACAA }\end{array}$ & 5 '-integration junction & 233 & Yang et al., 2006 \\
\hline
\end{tabular}


CA, USA), primers (0.08 $\mu \mathrm{M}$ of PEP3-5, PEP3-6, 4EPSPSF, 4EPSPSR; $0.16 \mu \mathrm{M}$ of Bar-CRP4, BarCFP4; $0.12 \mu \mathrm{M}$ of PatF, PatR for gene-specific reactions and $0.08 \mu \mathrm{M}$ of GT1F, GT1R, Rf3RV, Rf3RG; $0.1 \mu \mathrm{M}$ of $\mathrm{C}-1 \mathrm{~F}, \mathrm{C}-2 \mathrm{R} ; 0.16 \mu \mathrm{M}$ of Ms8RV-1, Ms8RG-1 for event-specific reactions), 1.0 U of Taq Polymerase (Applied Biosystems by Life Technologies, Thermo Fisher Scientific, Waltham, MA, USA) and $100 \mathrm{ng}$ of the genomic DNA template. Amplifications were carried out in a thermocycler (SensoQuest, Göttingen, Germany) at the following optimized parameters: initial denaturation of DNA at $96{ }^{\circ} \mathrm{C}$ for $4 \mathrm{~min}$; 5 cycles of $60 \mathrm{~s}$ at $94{ }^{\circ} \mathrm{C}, 1 \mathrm{~min}$ at $60^{\circ} \mathrm{C}$ and $2 \mathrm{~min}$ at $72{ }^{\circ} \mathrm{C}$. After pre-amplification, the main amplification was conducted in the following conditions: 35 cycles of $30 \mathrm{~s}$ at $94{ }^{\circ} \mathrm{C}, 30 \mathrm{~s}$ at $60{ }^{\circ} \mathrm{C}$ and $1 \mathrm{~min}$ at $72{ }^{\circ} \mathrm{C}$, followed by final extension at $72{ }^{\circ} \mathrm{C}$ for $5 \mathrm{~min}$ for the gene-specific reaction. The thermal cycling programme for the eventspecific reaction comprised initial denaturation of DNA at $96^{\circ} \mathrm{C}$ for $5 \mathrm{~min}, 40$ cycles of $45 \mathrm{~s}$ at $94^{\circ} \mathrm{C}$, $45 \mathrm{~s}$ at $60^{\circ} \mathrm{C}$ and $1 \mathrm{~min}$ at $72^{\circ} \mathrm{C}$, and a final extension at $72{ }^{\circ} \mathrm{C}$ for $5 \mathrm{~min}$.

\section{Amplified product detection}

Electrophoresis of the PCR products was performed in 2\% agarose (Thermo Fisher Scientific, Waltham, MA, USA) gels for approximately $60 \mathrm{~min}$ at $100 \mathrm{~V}$ in $1 \mathrm{x}$ Tris-borate-EDTA (TBE) buffer (Thermo Fisher Scientific, Waltham, MA, USA) and stained with ethidium bromide (EtBr) water solution $\left(0.5 \mu \mathrm{g} \cdot \mathrm{ml}^{-1}\right.$, Sigma-Aldrich, St. Louis, MO, USA) for DNA visualization.

\section{Validation parameters of $\mathrm{mPCR}$}

During validation of the mPCR method, the following parameters were tested: the efficiency of the CTAB extraction method, the influence of changing temperature (in the range of $65 \pm 2{ }^{\circ} \mathrm{C}$ ) of sample incubation on the extraction process, amplification specificity, sensitivity, accuracy and selectivity, the influence of changing PCR conditions, and the limit of detection (LOD). The efficiency of the CTAB extraction method and the impact of changing temperature of sample incubation on the extraction process were assessed by $260 / 280$ ratio measurements, indicating the purity and amount of extracted DNA. Amplification specificity, sensitivity and precision were evaluated by two series of PCR in which amplifiable target DNA amounts were present $(0.1 \% \mathrm{w} / \mathrm{w}$, which corresponded to the amount of $0.1 \mathrm{ng}$ of target DNA) or absent. The selectivity was verified using a mixture of DNA templates containing DNA of vari- ous GM plants and amplifiable amounts of the target DNA fragment $(0.1 \% \mathrm{w} / \mathrm{w})$. The robustness of $\mathrm{mPCR}$ in the changing amplification conditions was checked by modification of annealing temperature in the range of $\pm 2{ }^{\circ} \mathrm{C}$ (i.e. $58^{\circ} \mathrm{C}$ and $62{ }^{\circ} \mathrm{C}$ ) with respect to the optimized annealing temperature $\left(60^{\circ} \mathrm{C}\right)$, changed volume of reagents in the reaction mixtures in the range of $\pm 20 \%$ and modification of the DNA template amount (50 ng, $100 \mathrm{ng}, 200 \mathrm{ng}$ ) maintaining the final volume of $25 \mu$ l. Each of these validation reactions were performed in 20 replicates. The LOD was determined by analysis of samples containing a mixture of rapeseed GM and non-GM DNA with the final content of each line of GM rape equal to $10 \%$, $1 \%, 0.5 \%, 0.1 \%, 0.025 \%$ and $0.01 \%(\mathrm{w} / \mathrm{w})$. The low percentage mixtures were prepared by serial dilution. A total of $100 \mathrm{ng}$ of DNA from each GM maize mixture was used as a template in each reaction.

\section{Results and discussion}

Validation of the extraction process. DNA templates were extracted from 10 different samples of feedstuffs containing non-GM rape using the CTAB method. The 260/280 nm absorbance measured for the extracted DNA was always within the range of 1.7-2.0 indicating high quality of the extracted genetic material. The amount of extracted total DNA ranged from 108 to $140 \mathrm{ng} \cdot \mu \mathrm{l}^{-1}$. From each of the DNA templates, a fragment of the rape reference gene (248 bp) was amplified (Figure 1). Moreover, incubation of samples during the extraction process in changing temperature $\left(65 \pm 2{ }^{\circ} \mathrm{C}\right)$ did not influence the amount of obtained DNA and did not affect further amplification of the reference gene fragment (data not shown). These result demonstrat-

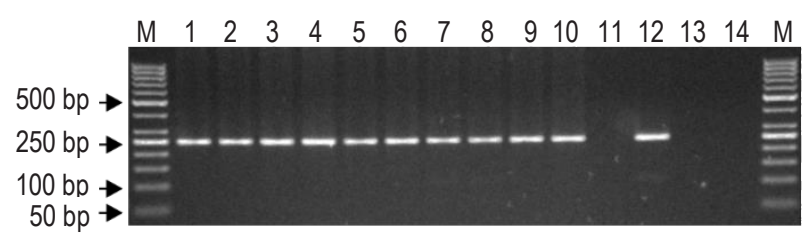

Figure 1. Multiplex PCR amplification results of pep gene fragment (248 bp) from DNA templates extracted from compound feed containing rape

$\mathrm{M}$ - low mass DNA leader 50 bp (Thermo Fisher Scientific, Waltham, MA, USA); lanes 1-10 - pep gene fragment amplified from DNA templates extracted from individual feedstuffs samples; lane 11 - negative reaction control (without DNA template); lane 12 - positive control (DNA of non-GM rape obtained from Certified Reference Materials); lane 13 - negative control for extraction process (DNA extraction reagents, no DNA template); lane 14 - negative control of environmental contamination (a test tube with water, remaining opened during DNA extraction process; the water was subsequently added to the PCR reaction mix instead of DNA template) 
ed that the CTAB method can be successfully used for isolation of DNA from feedstuffs. All extracted DNA samples were initially diluted to an equal concentration of $20 \mathrm{ng} \cdot \mu \mathrm{l}^{-1}$ in molecular grade water. The DNA solutions were directly used in PCR or subjected to further serial dilutions to the concentrations dependent of the type of the tested parameter.

mPCR-based detection and identification of GM rape. In the study, the gene-specific method to detect the reference gene fragment from rape and three fragments of genes (epsps, pat, bar) conferring resistance to two types of herbicides was choosen. Four primer pairs designed for this purpose yielded amplification products of different lengths. The PEP3-5, PEP3-6 primer pair was used to confirm the presence of the endogenous pep gene of rape encoding phosphoenolpyruvate phosphatase (248 bp product), while the 4EPSPSF, 4EPSPSR pair was used to detect the transgene fragment from the GT73 rape line (274 bp product). The other two primer pairs: Bar-CRP4, Bar-CFP4 (137 bp product) and PatF, PatR (108 bp product) were used to detect the fragment of the analysed gene conferring tolerance to glufosinate-ammonium in the Ms8xRf3 and $\mathrm{T} 45$ rape varieties, respectively.

It was demonstrated that additional pre-amplification with an elevated denaturation temperature and an extended step of primer annealing was necessary for efficient amplification of respective DNA targets in the gene-specific reaction (Figure 2).
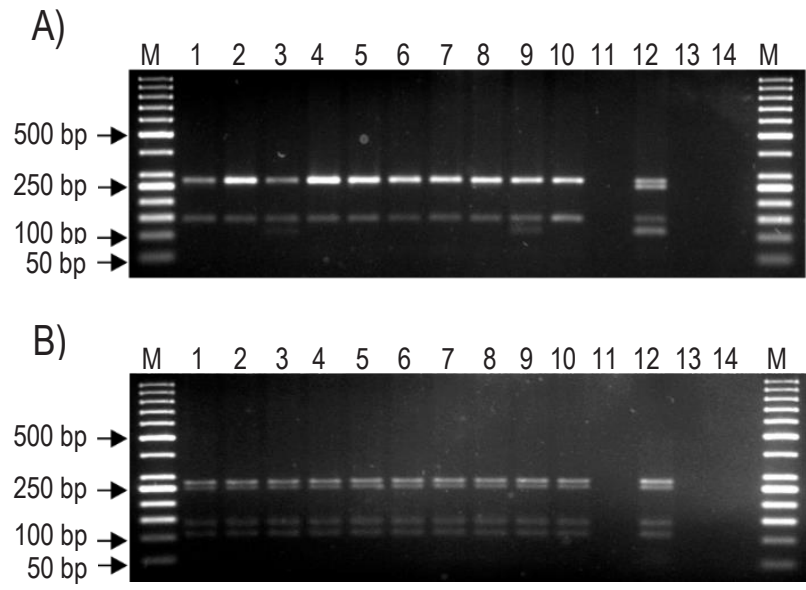

Figure 2. Multiplex PCR amplification results of gene-specific reaction: without pre-amplification (A) and with pre-amplification (B) in optimized conditions

$\mathrm{M}$ - low mass DNA leader 50 bp (Thermo Fisher Scientific, Waltham, MA, USA); lanes 1-10 - mixtures of DNA templates of rape lines GT73, Ms8 or Rf3, and T45 (10 individual mixtures); lane 11 - negative reaction control (without DNA template); lane 12 - positive control (DNA of non-GM rape obtained from Certified Reference Materials); lane 13 - negative control for extraction process (DNA extraction reagents, no DNA template); lane 14 - negative control of environmental contamination (as described in Figure 1)
Only these conditions allowed amplification of each of the specific fragments in this type of reaction.

The event-specific primer pair GT1F, GT1R was used for detection of the GT73 rape and resulted in amplification of the specific DNA fragment comprising the 3 ' end of the pea $r b c \mathrm{~S}-\mathrm{E} 9$ gene (E9 3') and the rape genome. For identification of the Ms8 and Rf3 event, Ms8RV-1, Ms8RG-1 and Rf3RV, Rf3RG primer pairs were used, respectively, allowing detection of the host DNA sequence and the right border of the transgene junction site. The primers $\mathrm{C}-1 \mathrm{~F}, \mathrm{C}-2 \mathrm{R}$ were used for $\mathrm{T} 45$ rape event identification based on amplification of the 5 ' junction region between the host DNA and exogenous sequence originating from the CaMV35S promoter. The standard PCR profile (without additional preamplification) was sufficient in the event-specific reaction to obtain successful amplification of all desired fragments (Figure 3). However, the composition of the reaction mixtures as well as the reaction conditions related to the temperature and time of the individual steps were subjected to optimization (the final optimized conditions are specified in the Material and methods section), contributing to achievement of appropriate efficiency of expected fragments amplification for each GM rape variety.

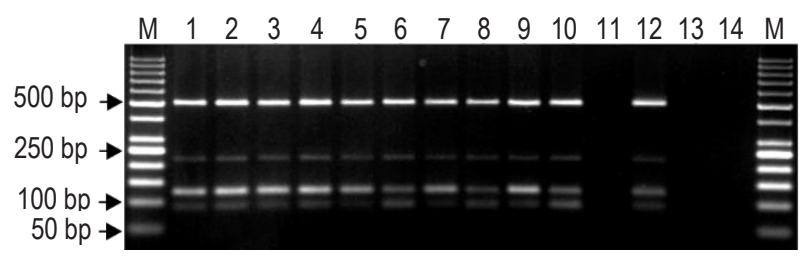

Figure 3. Multiplex PCR amplification results of event-specific reaction in optimized conditions

$\mathrm{M}$ - low mass DNA leader 50 bp (Thermo Fisher Scientific, Waltham, MA, USA); lanes 1-10 - mixtures of DNA templates of rape lines GT73, Ms8 or Rf3, and T45 (10 individual mixtures); lane 11 - negative reaction control (without DNA template); lane 12 - positive control; lane 13 - negative control for extraction process (DNA extraction reagents, no DNA template); lane 14 - negative control of environmental contamination (as described in Figure 1)

Summarizing, the mPCR method developed in this work allowed simultaneous detection of more than one DNA fragments indicating GM events in the single reaction. In gene-specific PCR, two fragments were amplified in all tested samples: an endogenous gene and a fragment specific for individual transgenes. In event-specific PCR, a fragment characteristic for individual lines comprising the junction border between the insert and the host genome was obtained. 
In-house validation. In-house validation involving determination of the specificity, selectivity, accuracy and limit of detection (LOD) of the developed mPCR method was performed. The specificity of amplification was tested using DNA of other GM plants. The test was performed for DNA samples isolated from soyabean GTS 40-3-2, 305423 and 356043, maize: Bt11, Bt176, MON810, T25, GA21, MIR604, MON863, NK603, 1507, 59122 and cotton 281-24236x3006-210-23, GHB119. Several DNA fragments were amplified in the specificity tests of the gene-specific reactions. An amplification fragment of the epsps gene was obtained from the DNA of soyabean GTS 40-3-2 and maize NK603. The fragment of the bar gene was amplified from the DNA of maize Bt176 and cotton GHB119, and fragments characteristic for the pat gene were detected after amplification from the DNA of maize lines: Bt11, 1507, 59122, and cotton 281-24-236x3006-210-23 (Figure 4A). Importantly, no amplification products were obtained in the event-specific reaction with DNA templates from other GM plants tested above (Figure 4B).

Positive results obtained in specificity tests of gene-specific reactions for other than rape varieties of GM plants are associated with the introduction of the same target genes in various kinds of GM plants. However, taking into consideration the results obtained in the event-specific reaction, the sensitivity and accuracy of the developed method were estimated, and the values of these parameters reached $100 \%$ for all rape lines. It may be concluded that the developed event-specific mPCR method can be
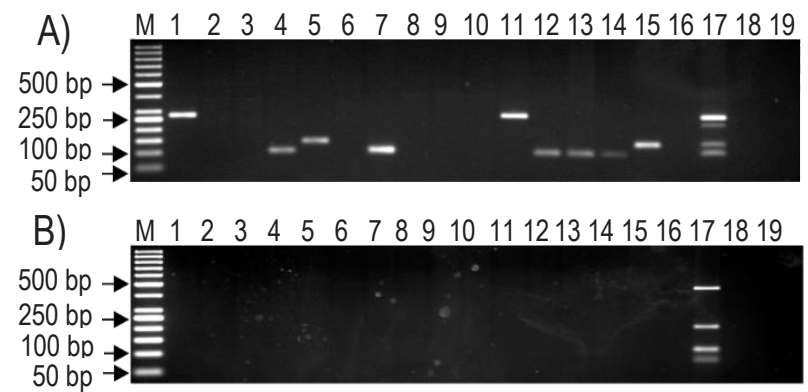

Figure 4. Amplification results of specificity test for gene-specific reaction $(A)$ and event-specific reaction $(B)$ using DNA templates of other than rape $\mathrm{GM}$ plants

$M$ - low mass DNA leader 50 bp (Thermo Fisher Scientific, Waltham, MA, USA); lanes 1-15 - DNA of soyabean: GTS 40-3-2, 2305423 and 356043, DNA of maize: Bt11, Bt176, MON810, T25, GA21, MIR604, MON863, NK603, 1507 and 59122, DNA of cotton 281-24-236x3006210-23 and GHB119; lane 16 - negative reaction control; lane 17 positive control, DNA from all tested GM rape varieties; lane 18 - negative control for extraction process (DNA extraction reagents, no DNA template); lane 19 - negative control of environmental contamination (as described in Figure 1) widely used for identification of a GM event allowing effective, reliable and highly specific results.

During the analysis of the selectivity of the gene- and event-specific reactions, it was shown that properly optimized reactions and appropriately selected primers allowed selective amplification of target DNA, which concentration in the mixture with foreign DNA did not exceed $0.1 \%(\mathrm{w} / \mathrm{w})$ (which corresponds to $0.1 \mathrm{ng}$ ). Positive amplification was obtained for each type of the reactions (Figures 5A and $5 \mathrm{~B})$.

In order to determine the resistance of the GM rape detection methods to changing amplification parameters, both gene- and event-specific reactions were performed at varying primer annealing temperatures in the range of $60 \pm 2{ }^{\circ} \mathrm{C}$ and in reaction mixtures with altered proportions of components $\pm 20 \%$. Each test gave a correct positive result, indicating that the validated method is highly resistant to changes in the amplification parameters (data not shown).

The limit of detection (LOD) of the method was determined by verifying the amplification ability of desired DNA fragments from DNA templates containing the mixture of rapeseed GM and nonGM DNA with the final concentration of each line of GM rape ranging from $10 \%$ to $0.01 \%(\mathrm{w} / \mathrm{w})$. For the gene-specific reactions, the limit of detections was determined at $0.01 \%(\mathrm{w} / \mathrm{w})$. The single band with a size of $248 \mathrm{bp}$ observed in lane 7 comprises only an amplicon of the rape reference pep gene,
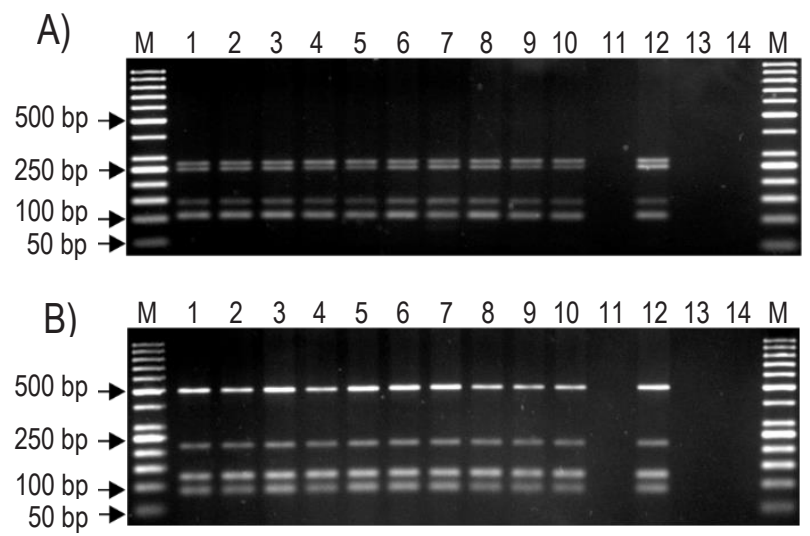

Figure 5. Amplification results of selectivity test for gene-specific reaction (A) and event-specific reaction (B)

$M$ - low mass DNA leader 50 bp (Thermo Fisher Scientific, Waltham, MA, USA); lanes 1-10 - mixtures of DNA templates in which DNA content of individual GM rape (GT73, Ms8, Rf3, T45) did not exceed $0.1 \%$ (which correspond to $0.1 \mathrm{ng}$ of DNA); lane 11 - negative reaction control; lane 12 - positive control, DNA sample of the individual GM rape events; lane 13 - negative control for extraction process (DNA extraction reagents, no DNA template); lane 14 - negative control of environmental contamination (as described in Figure 1) 
as it was amplified from a DNA template comprising only non-GM rape (Figure 6A). For the eventspecific reaction, the LOD value was determined at $0.01 \%(\mathrm{w} / \mathrm{w})$ for the GT73, Ms8 and Rf3 rape lines, and $0.025 \%(\mathrm{w} / \mathrm{w})$ for T45 rape (Figure $6 \mathrm{~B})$. Both developed assays displayed higher sensitivity than a similar multiplex PCR-based reaction dedicated for GM rape detection as previously stated by Demeke et al. (2002) and Kim et al. (2007). It should be noticed that the obtained LOD levels were absolutely optimal for the multiplex PCR method used for GMO content monitoring in feedstuffs in Poland.

The results obtained in the validation process indicated that the optimized PCR were suitable for detection and identification of genetically modified rape. The reactions exhibited high specificity, sensitivity and accuracy. Moreover, the developed $\mathrm{mPCR}$ were highly selective and resistant to changes during both template extraction and DNA amplification. The main advantage of application of MPCR in this type of analysis is reduction of sample loads, time and resources: the developed method allows simultaneous amplification of several targets in one reaction. Similar detection/identification systems have been
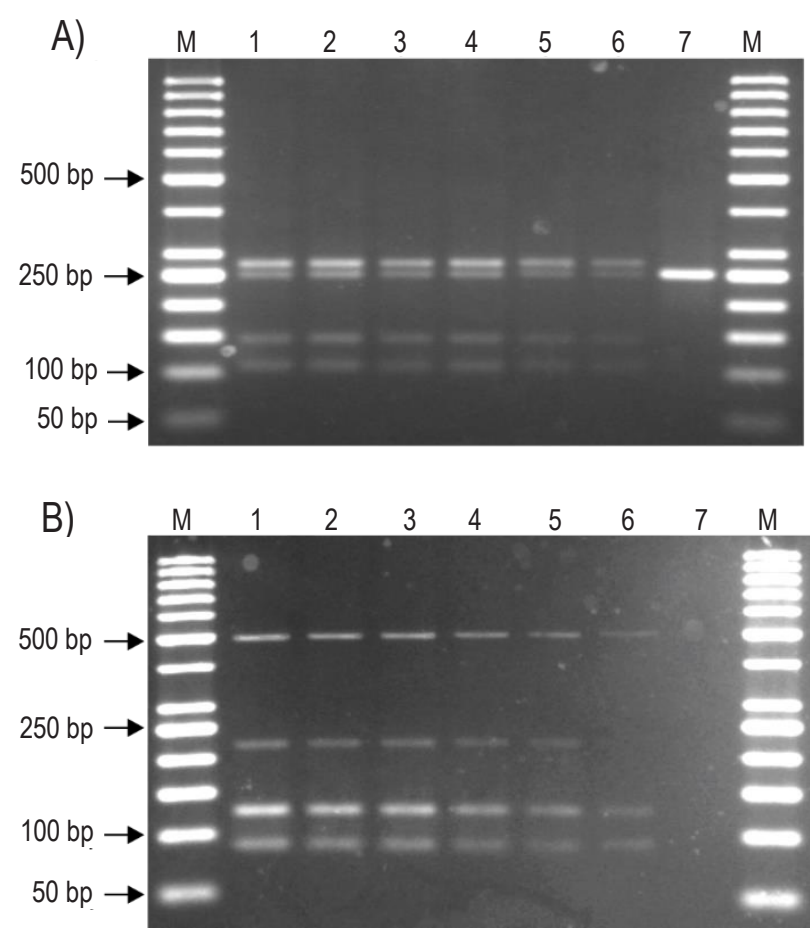

Figure 6. Amplification results of limit of detection (LOD) test for genespecific reaction $(A)$ and event-specific reaction $(B)$

PCR products were amplified from mixture of GT73, Ms8 and T45 DNA and other DNA from non-GM rape; $M$ - low mass DNA ladder 50 bp (Thermo Fisher Scientific, Waltham, MA, USA); lanes 1-7 - amplification of desired DNA fragments from templates containing $10 \%, 1 \%$, $0.5 \%, 0.1 \%, 0.025 \%, 0.01 \%$ and $0 \%(\mathrm{w} / \mathrm{w}$ ) of DNA from all tested $\mathrm{GM}$ rape varieties, respectively developed previously for a number of GMOs (James et al., 2003; Germini et al., 2004; Forte et al., 2005; Kim et al., 2007; Demeke and Ratnayaka, 2008). Moreover, the highly specific event-specific reaction, which follows the gene-specific reaction, confirms the presence and allows identification of a particular GMO in the tested sample, which was demonstrated in this study.

Analysis of GM rape from unknown samples. During the period from 2012 to 2015, in the Department of Hygiene of Animal Feedingstuffs, National Veterinary Research Institute (Poland), 428 samples of animal feedstuffs containing oilseed rape were analysed for the presence of GM rape. The tested material comprised 279 post-extraction rapeseeds, 24 rapeseeds, 28 rapeseed cakes and 97 compound feed samples. In each tested samples, amplification of a fragment of the rape reference gene ( $248 \mathrm{bp}$ ) was observed. The 274-bp DNA fragment, indicating the presence of the epsps transgene conferring resistance to glyphosate herbicide, was detected in 8 out of 50 feedstuff samples analysed between 2012 to 2013 . Concomitantly, during this time, no DNA fragment characteristic for the GT73 rape was detected in the event-specific reaction amplification, allowing a conclusion that these samples were negative with respect to the presence of the GM rape. Nevertheless, these samples have been checked for the content of other GM plant (soyabean in this case) and GM soyabean was actually found in these samples. However, the situation changed in 2014-2015: in 55 of the 232 tested samples, the epsps gene fragment was amplified in the gene-specific reaction and a DNA fragment characteristic for GT73 lines of GM rape was observed in the event-specific reaction. Because cultivation of GM plants in Poland is prohibited, we have checked the origin of the samples, gaining evidence that they were brought from any of neighbouring countries. Since rape has a natural ability of mating with related species and the transgene from GM rape could be easily transferred to other plants, one should pay more attention to control against the presence of GM rape in feedstuffs especially in ecological plant production considered as GMO-free crops. Otherwise, uncontrolled spreading of GM rape is very plausible.

\section{Conclusions}

Successful development of molecular methods for detection and identification of genetically modified organisms (GMOs) is an important area of research, especially in countries in which food and feedstuff products containing GMOs must be 
labelled appropriately with respect to the EU regulations. Multiplex PCR assays, allowing detection of several genetic targets at the same time, offer a sensitive and reliable method for GMO identification. Moreover, they allow reduction of cost and turnaround time of sample analyses. As demonstrated, these assays are suitable for identification of various lines of GM rape in animal feedstuffs.

\section{References}

Datukishvili N., Kutateladze T., Gabriadze I., Bitskinashvili K., Vishnepolsky B., 2015. New multiplex PCR methods for rapid screening of genetically modified organisms in foods. Front. Microbiol. 6, 757, https://doi.org/10.3389/fmicb.2015.00757

Demeke T., Giroux R.W., Reitmeier S., Simon S.L., 2002. Development of a polymerase chain reaction assay for detection of three canola transgenes. J. Am. Oil Chem. Soc. 79, 1015-1019, https://doi.org/10.1007/s11746-002-0595-2

Demeke T., Ratnayaka I., 2008. Multiplex qualitative PCR assay for identification of genetically modified canola events and real-time event-specific PCR assay for quantification of the GT73 canola event. Food Control 19, 893-897, https://doi. org/10.1016/j.foodcont.2007.08.020

Dobnik D., Štebih D., Blejec A., Morisset D., Žel J., 2016. Multiplex quantification of four DNA targets in one reaction with Bio-Rad droplet digital PCR system for GMO detection. Sci. Rep. 6, 35451, https://doi.org/10.1038/srep35451

Dörries H.-H., Remus I., Grönewald A., Grönewald C., BerghofJäger K., 2010. Development of a qualitative, multiplex realtime PCR kit for screening of genetically modified organisms (GMOs). Anal. Bioanal. Chem. 396, 2043-2054, https://doi. org/10.1007/s00216-009-3149-2

Elsanhoty R.M., Al-Turki A.I., Ramadan M.F., 2013. Prevalence of genetically modified rice, maize, and soy in Saudi food products. Appl. Biochem. Biotechnol. 171, 883-899, https://doi. org/10.1007/s12010-013-0405-x

EN ISO 21571:2005. Foodstuffs - Methods of analysis for the detection of genetically modified organisms and derived products Nucleic acid extraction. https://www.iso.org/standard/34616. $\mathrm{html}$

Fernandes T.J.R., Amaral J.S., Oliveira M.B.P.P., Mafra I., 2014. A survey on genetically modified maize in foods commercialised in Portugal. Food Control 35, 338-344, https://doi.org/10.1016/j. foodcont.2013.07.017

Forte V.T., Di Pinto A., Martino C., Tantillo G.M., Grasso G., Schena F.P., 2005. A general multiplex-PCR assay for the general detection of genetically modified soya and maize. Food Control 16, 535-539, https://doi.org/10.1016/j.foodcont.2004.05.010

Gerdes L., Iwobi A., Busch U., Pecoraro S., 2016. Optimization of digital droplet polymerase chain reaction for quantification of genetically modified organisms. Biomol. Detect. Quantif. 7, 9-20, https://doi.org/10.1016/j.bdq.2015.12.003

Germini A., Zanetti A., Salati C., Rossi S., Forré C., Schmid S., Marchelli R., 2004. Development of a seven-target multiplex PCR for the simultaneous detection of transgenic soybean and maize in feeds and foods. J. Agric. Food Chem. 52, 3275-3280, https://doi.org/10.1021/jf035052x

Hellebrand M., Nagy M., Mörsel J.-T., 1998. Determination of DNA traces in rapeseed oil. Z. Lebensm. Unters. Forsch. 206, 237-242, https://doi.org/10.1007/s002170050250
Holst-Jensen A., Bertheau Y., de Loose M. et al., 2012. Detecting unauthorized genetically modified organisms (GMOs) and derived materials. Biotechnol. Adv. 30, 1318-1335, https://doi. org/10.1016/j.biotechadv.2012.01.024

Holst-Jensen A., Ronning S.B., Lovseth A., 2003. PCR technology for screening and quantification of genetically modified organisms (GMOs). Anal. Bioanal. Chem. 375, 985-993, https:// doi.org/10.1007/s00216-003-1767-7

Iwobi A., Gerdes L., Busch U., Pecoraro S., 2016. Droplet digital PCR for routine analysis of genetically modified foods (GMO) - A comparison with real-time quantitative PCR. Food Control 69, 205-213, https://doi.org/10.1016/j.foodcont.2016.04.048

James D., Schmidt A.-m., Wall E., Green M., Masri S., 2003. Reliable detection and identification of genetically modified maize, soybean and canola by multiplex PCR analysis. J. Agric. Food Chem. 51, 5829-5834, https://doi.org/10.1021/jf0341159

Kim J.-H., Kim T.-W., Lee W.-Y., Park S.-H., Kim H.-Y., 2007. Multiplex PCR detection of the GT73, MS8xRF3, and T45 varieties of GM canola. Food Sci. Biotechnol. 16, 104-109

Kim J.-H., Zhang D., Kim H.-Y., 2014. Detection of sixteen genetically modified maize events in processed foods using four eventspecific pentaplex PCR systems. Food Control 35, 345-353, https://doi.org/10.1016/j.foodcont.2013.07.029

Marmiroli N., Maestri E., Gulli M., Malcevschi A., Peano C., Bordoni R., De Bellis G., 2008. Methods for detection of GMOs in food and feed. Anal. Bioanal. Chem. 392, 369-384, https://doi. org/10.1007/s00216-008-2303-6

Meriç S., Çakır Ö., Turgut-Kara N., Arı Ş., 2014. Detection of genetically modified maize and soybean in feed samples. Genet. Mol. Res. 13, 1160-1168, https://doi.org/10.4238/2014.February. 25.2

Miraglia M., Berdal K.G., Brera C. et al., 2004. Detection and traceability of genetically modified organisms in the food production chain. Food Chem. Toxicol. 42, 1157-1180, https://doi. org/10.1016/j.fct.2004.02.018

Özgen Arun Ö., Yılmaz F., Muratoğlu K., 2013. PCR detection of genetically modified maize and soy in mildly and highly processed foods. Food Control 32, 525-531, https://doi.org/10.1016/j. foodcont.2013.01.023

Santa-Maria M.C., Lajo-Morgan G., Guardia L., 2014. Adventitious presence of transgenic events in the maize supply chain in Peru: a case study. Food Control 41, 96-101, https://doi. org/10.1016/j.foodcont.2014.01.006

Shin K.-S., Suh S.-C., Lim M.-H., Woo H.-J., Lee J.H., Kim H.-Y., Cho H.-S., 2013. Event-specific detection system of stacked genetically modified maize by using the multiplex-PCR technique. Food Sci. Biotechnol. 22, 1763-1772, https://doi. org/10.1007/s10068-013-0278-3

Turkec A., Lucas S.J., Karlık E., 2016. Monitoring the prevalence of genetically modified maize in commercial animal feeds and food products in Turkey. J. Sci. Food Agric. 96, 3173-3179, https://doi.org/10.1002/jsfa.7496

Wu G., Wu Y., Xiao L., Lu C., 2008. Event-specific qualitative and quantitative polymerase chain reaction methods for detection of genetically modified rapeseed Ms8Rf3 based on the right border junctions. J. AOAC Int. 91, 143-151

Yang L., Pan A., Zhang H., Guo J., Yin C., Zhang D., 2006. Event-specific qualitative and quantitative polymerase chain reaction analysis for genetically modified canola T45. J. Agric. Food Chem. 54, 9735-9740, https://doi.org/10.1021/jf061918y

Yang R., Xu W., Luo Y., Guo F., Lu Y., Huang K., 2007. Event-specific qualitative and quantitative PCR detection of roundup ready event GT73 based on the 3'-integration junction. Plant Cell Rep. 26, 1821-1831, https://doi.org/10.1007/s00299-007-0385-9 
Zdjelar G., Nikolić Z., Vasiljević I., Bajiić B., Jovičić D., Ignjatov M. Milošević D., 2013. Detection of genetically modified soya, maize, and rice in vegetarian and healthy food products in Serbia. Czech J. Food Sci. 31, 43-48
Zeitler R., Pietsch K., Waiblinger H.-U., 2002. Validation of real-time PCR methods for the quantification of transgenic contaminations in rape seed. Eur. Food Res. Technol. 214, 346-351, https://doi.org/10.1007/s00217-001-0454-1 